CHAPTER 4:

\title{
Civic and Citizenship Education in Colombia: Challenges for Students and Teachers
}

\author{
Luis Felipe Dussán Zuluaga and Juan Camilo Ramírez Chaguendo
}

\begin{abstract}
Civic and citizenship education in Colombia has changed over the last two decades. The socioeconomic context and internal armed conflict, among other issues, have influenced the way that students have been taught. Several studies have been carried out to assess teaching about these topics in the country. This chapter briefly discusses the contribution IEA's International Civic and Citizenship Education Study (ICCS) has made to civic and citizenship education in Colombia and discusses the possible causes of the performance of the country in this study, as well as possible steps for its improvement. It also discusses how teachers' training, schools' autonomy, and limited resources for pedagogical improvement could be related to these results.
\end{abstract}

\section{Introduction}

Research on civic and citizenship education is crucial for understanding the contexts in which this topic is taught, and the competences students are developing. This chapter considers aspects that could affect the citizenship attitudes of young students, as well as the social and political behaviour of current and future generations. It, therefore, represents an opportunity to gather relevant data for the design of education policies to help achieve specific educational goals. Similarly, studies of civic and citizenship education provide information on how this subject is taught within schools. This is a key source to ascertain how political efforts (e.g., relevant educational reforms, laws, projects) are being implemented inside schools (Valencia 2019).

Colombia, as defined by its Constitution (1991, Article 1), is a democratic, participatory and pluralistic country, based on human dignity, joint interest, solidarity, and work. From this statement, it can be inferred that citizens should be educated through the lenses of human rights, peace, and democracy. In addition, Article 41 states that the study of the Constitution and civic instruction is mandatory in schools; thus, principles and values related to citizenship participation should be promoted within the school. This sets the ground rules for guidelines detailing what students should be taught in subjects related to civics and citizenship.

Currently, civic and citizenship education in Colombia is based on the Standards of Citizenship Competences designed by the Ministry of National Education in 2003: a set of cognitive and non-cognitive competences needed for the conscious and responsible exercise of citizenship in the social and political realms. These documents are intended to serve as one of the guidelines for teachers to build their curriculum.

However, it is often difficult for teachers to teach civic and citizenship education in the way that the constitution and the educational law requires and to promote the competences established in the Standards of Citizenship Competences. In addition to the lack of supportive material mentioned, the political, economic, and social contexts of the country have influenced the topics covered in this subject (Herrera 2008a). As the Ministry of Education (2011) recognizes, "in a country like ours, marked by a history of inequity, violence and exclusion, the challenge is not simply to train people to follow rules without question, instead we needed people to commit

Luis Felipe Dussán Zuluaga, Colombian Institute for Educational Assessment and Evaluation (Icfes) (Instituto Colombiano para la Evaluación de la Educación), Bogota, Colombia

email: luisfelipedussan@gmail.com

Juan Camilo Ramírez Chaguendo, Colombian Institute for Educational Assessment and Evaluation (Icfes) (Instituto Colombiano para la Evaluación de la Educación), Bogota, Colombia email: juanrachag@gmail.com

(C) IEA International Association for the Evaluation of Educational Achievement 2021 
to society in a critical sense, to be individuals that participate actively and feel co-responsible in building a democratic community that assumes inclusion" (p.18). Further, teaching in civic and citizenship education is often related to ethics and peace-related content, which is taught as a requirement by law in Colombia. However, this does not always have a strong dimension of democracy and inclusion (González 2013). Because of a necessary focus on pervasive problems of conflict in some areas, other aspects of civic education sometimes get little attention.

To provide some context, at about the same time as the implementation of the Standards, in 2016 Colombia moved towards the end of 60 years of internal armed conflict with one of the guerrilla groups, the FARC.1, 2 This began what is called the post-accord era. However, a serious challenge remains, which is related to socioeconomic inequity and poverty and to political conflicts (ideological intolerance and the limitations on equal opportunities for political participation) (Ramirez-Orozco 2014). It has been demonstrated that in countries that are in a post-agreement process, civic and citizenship education has a key role in the restoration of the social structure of the society. Teaching about these topics is crucial to enable new generations to understand the consequences of conflict and to contribute to the construction of a democracy that can deal with these social issues (Bickmore et al. 2017). This could be part of the reason why peace-building in Colombia is one of the main topics of civic and citizenship education. It is important to mention that since the signature of the peace agreement education has been seen as the most important tool to establish peace in the country. That is why citizenship education became one of the strategies in the country for recovering historical memories throughout forgiveness processes and reconciliations (Chaux et al. 2017). For this reason, the government established the Law 1732 of 2014: Cátedra de la Paz (Peace Seminar), to "promote the process of appropriation of knowledge and skills related to ... culture, economic and social context and historical memory, with the purpose of rebuilding the social fabric, promoting general prosperity and the effectiveness of principles, rights and obligations enshrined in the Constitution" (Congreso de la República de Colombia 2014).

In this educational and social context, the Colombian Institute for Educational Assessment and Evaluation (Icfes) (Instituto Colombiano para la Evaluación de la Educación) has recognized the importance of civic and citizenship competences. It is one of the areas assessed in the National Standardized Tests, which includes instruments to measure citizenship attitudes, actions, and thinking, as well as socioemotional abilities. In addition, the Institute also administers and analyzes results of several international studies that assess civic and citizenship education like the IEA ${ }^{3}$ ICCS (International Civic and Citizenship Education Study), the Global Competence component of the OECD 4 PISA (Programme for International Student Assessment), and the OECD Study on Social and Emotional Skills (SSES).

In particular, ICCS 2016 showed that levels of students' civic knowledge were low in Latin American countries compared to other countries that participated in the study. However, when considering the previous cycle (ICCS 2009), Colombia exhibited an improvement and placed more students in the highest proficiency levels: $52.8 \%$ of students in ICCS 2016, as opposed to $42.7 \%$ in ICCS 2009. These results were high when compared to Chile, Mexico, Peru, and Dominican Republic.

This chapter briefly discusses the contributions IEA's ICCS, and the earlier Civic Education Study (CIVED), have made to civic and citizenship education in Colombia and debates some of the challenges and possible steps for improvement of education in this subject. The chapter was

$1 \quad$ FARC = Fuerzas Armadas Revolucionarias de Colombia (Revolutionary Armed Forces of Colombia).

2 It is important to mention that FARC it is just one of the guerilla groups in the country, peace processes involve more than what is said in this section of the document.

3 IEA = International Association for the Evaluation of Educational Achievement.

$4 \mathrm{OECD}=$ Organisation for Economic Co-operation and Development. 
written based on a literature review, fieldwork, and consultation with experts. ${ }^{5}$ It begins with a description of the historical background of civic and citizenship education in the country, followed by the presentation of data from both ICCS cycles (2009 and 2016) in which Colombia has participated, and the influence the study has had on both the Colombian National Standardized Test of Citizenship Competences and the Test of Citizen Actions and Attitudes. Also considered is the dissemination of national results of ICCS 2016 among teachers and principals around the country. Finally, it briefly examines the context and limitations of civic and citizenship education in Colombia and presents some policy recommendations.

\section{The Context of Civic and Citizenship Education in Colombia and Teachers' Roles}

Given the sociodemographic, ethnic, and cultural diversity in the country, Colombia's national education policy is based on schools' autonomy. This is grounded on the premise that each school has the capacity to develop and assess its own curriculum, as well as implement teaching practices (Patti and Espinosa 2007). This decentralized education system means that there is no official national curriculum that integrates civic and citizenship competences (Chaux et al. 2007). However, the Ministry of National Education, through its role as the policymaker in education, suggests general guidelines to schools, providing recommendations that are supported by its own programs or allied educational organizations (Congreso de la República de Colombia 1994a, 1994b; Chaux 2009).

The goal of the Colombian educational system is to prepare students to claim their rights, comply with their duties, recognize what is right from wrong in legal terms, and to build a fair and equitable society (Rodríguez et al. 2007). This perspective has taken greater relevance since the Constitution of 1991, which focused strongly on human rights and instituted a participative democracy that encourages the active involvement of citizens in the political structure, stimulating debate around moral and citizenship education (Jaramillo and Mesa 2009; Peláez and Márquez 2006).

Additionally, the 1994 General Law of Education promotes civic and citizenship education, supporting the consolidation of a democratic political culture and pursuing both political legitimation and social cohesion (Herrera et al. 2003; Herrera 2008b). This Act explicitly supports the autonomy of schools by eliminating the single curriculum: The State does not control the contents nor the teaching methodology within schools, and teachers do not have to follow a government-established curriculum (Salas 2019). This also applies to the field of civic and citizenship education. However, this autonomy is not only for the schools. One of the main purposes of Colombian 1991 Constitution is to consolidate the country as a decentralized unique republic. In this sense, local authorities have autonomy to administer public local services, which includes education resources and decisions. The purpose of the decentralization is to improve the wealth and life quality of people all over the country (Largo et al. 2014). The above shows that there is an additional aspect that should be considered when the Colombian educational system is analyzed.

However, the General Law of Education clarifies that reading, math, science, social sciences, arts, ethics, religion, history, geography, political constitution, and democracy, are mandatory and fundamental subjects (together, these should represent a minimum $80 \%$ of the curriculum). Similarly, the Ministry of Education has legislated to ensure an annual minimum of teaching hours to enable schools to cover the prescribed curriculum.

5 The authors, who are part of the Icfes team, thank Natalia González, Ana María Restrepo-Saénz, Carolina Valencia, Yuliana Salas, Delvi Gómez, Alejandra Forero, Katherine Guerrero, and Miguel Moreno for their interest and comments. 
In response to different social, economic, and political issues that Colombia faces, for instance, socioeconomic discrimination, inequality, violence, drug traffic, among other problems (Pinilla and Torres 2006; Restrepo 2006; Jaramillo and Mesa 2009; Bickmore et al. 2017; GonzálesValencia and Santisteban-Fernández 2016; Browse 2017), the Ministry of National Education elaborated an ambitious civic and citizenship program in 2003. This program sought to strengthen the role of education through a guide for educators that imparted knowledge about programs and practices that could help to develop important life skills in children and youth (Ministerio de Educación Nacional [MEN] 2004; Patti and Espinosa 2007; Jaramillo and Mesa 2009). Thus, this effort encouraged the design of practical pedagogical strategies, as opposed to more traditional methods (Chaux 2009; Chaux et al. 2012): for example, instead of asking the student to provide the definition of corruption, the teacher would present a situation and ask the students to give reasons why it would or would not be considered a case of corruption.

In order to do this, the Ministry brought together researchers and experts in civic and citizenship education to construct the Standards of Citizenship Competences, which would serve as a guide for what students should learn in school, in line with the emphasis on citizenship education in the Constitution of 1991. The general guidelines specify the civic and citizenship competences that students should acquire in their years of schooling and suggest paths of action and decision making in real-life settings (Peláez and Márquez 2006).

The standards were defined as a set of cognitive, emotional, integrative, and communicative competences needed for the conscious and responsible exercise of citizenship in the political field, respecting, spreading, defending, guaranteeing, and restoring their rights (MEN 2011). The aims include supporting peaceful coexistence, promoting democratic participation and civic responsibility, and promoting the equal dignity of human beings. With the creation of these standards, the government sent an explicit message about the importance of this subject in schools (Berkowitz and Bustamante 2013).

The standards defined cognitive, emotional, communication, and integrative skills (Icfes 2018):

- Cognitive skills-the knowledge necessary to participate democratically, build coexistence, and value pluralism;

- Emotional skills-those that allow people to recognize, understand, and appropriately regulate their own emotions and recognize those of others;

- Communication skills-those that allow the effective transmission and reception of ideas and opinions, and enable constructive dialogues; and

- Integrating skills-those that connect the previous ones in a coherent way to encourage the consolidation of citizen attitudes and the exercise of citizenship actions.

The notion of competences involves both knowing and practicing, which means that simple knowledge is not enough to guide "good" citizen actions. Chaux (2009) and Chaux et al. (2012) point out that it is also necessary to know how to take one's rights into action.

Based on this framework, the Ministry appointed Icfes to assess the improvement of civic and citizenship competences within the country. With reference to the Standards of Citizenship Competences, the national regulations, and the advice of experts in the field, Icfes designed and validated two instruments: the National Test of Citizenship Competences and the National Test of Citizen Actions and Attitudes (for grades 5 and 9). While the first assesses cognitive skills through multiple-choice questions with a single correct response, the second collects data on emotional and integrative competences through attitude scales asking about the frequency of behaviour for which there are no correct answers (Icfes 2018). These tests explore understandings, beliefs, perceptions, attitudes, and actions about aspects of citizenship and participation. Specifically, this includes those that involve putting into practice emotional and integrative competences in interpersonal relationships (coexistence and peace, plurality, identity, and assessment of 
diversity), and the relationship one might have with the institutions (participation and democratic responsibility) (Icfes 2013). These are administered to students in grades 5 and 9. In contrast, the test that assesses cognitive competences is administered to students in grades 5, 9, and 11, as well as to students in universities.

Concurrently with assessing civic and citizenship competences within the country, there have been local and institutional initiatives related to peace education, human rights, conflict resolution, and youth leadership, some of them established by the Ministry of Education, others by private institutions, and some by both. For example, private programs like Hermes Program (Programa Hermes), Life Skills (Habilidades para la Vida), Peace Games (Juegos de Paz), Classrooms in Peace (Aulas en Paz), among others (MEN 2006a), and programs from the Ministry of Education that blend approaches like Learning Network (Red aprender). On the other hand, in addition to these programs and initiatives, the Peace Seminar (Cátedra de la Paz) was established by Law in all schools in 2015 (Congreso de la República de Colombia 2015). This program seeks to generate more peaceful environments by promoting emotional, cognitive, and communicative abilities or strategies as part of civic and citizenship education (Jaramillo and Mesa 2009).

Furthermore, when talking about Latin-American projects, it is important to mention the Regional System of Evaluation and Development of Citizenship Competences (Sistema Regional de Evaluación y Desarrollo de Competencias Ciudadanas) led by Colombia and funded by the InterAmerican Development Bank, which aims to contribute to civic and citizenship competences construction in the region through the strengthening of education for the citizenship and democracy (Icfes 2018).

As mentioned, the General Law of Education of 1994 allowed schools to decide the specific content and pedagogical practices to teach each subject (school autonomy). Therefore, schools and teachers play a significant role in the development of civic and citizenship competences. In practice, schools traditionally delegate civic and citizenship education to social sciences teachers, de-emphasizing the idea of citizenship education as a transversal project (GonzálezValencia and Santisteban-Fernández 2016). This is a critical issue because many argue that civic and citizenship instruction should not be limited to just one subject; on the contrary, it should be an overarching theme in all school subjects. At the same time schools and teachers' beliefs have often shaped the way that civic and citizenship competences are taught, which represents another challenge for the implementation of the Standards.

Finally, the Constitution gives autonomy to local authorities to guide and be responsible for education in their jurisdiction. However, some local authorities do not have the required resources to thoughtfully examine the teaching plans that are being followed in each school, and therefore they cannot give them the support they need. This limited information hinders the Ministry of National Education's knowledge about how civic and citizenship competences are being developed within the schools. This is a major concern, because of the belief that the whole educational institution system should be involved (Icfes 2018).

\section{Colombia's Participation in ICCS and its Influence on Icfes' Assessments of Civic and Citizenship Competences}

This section presents the main results of Colombia in ICCS 2016 compared to ICCS 2009 and describes the contribution of the study to the creation of both the National Standardized Test of Citizenship Competences and the Test of Citizen Actions and Attitudes, taking into account the ICCS aim related to investigating how young people (14-year-olds) are prepared to undertake their roles in different countries (Schulz et al. 2016). It also describes the dissemination of results among teachers across the country. 


\section{National Results}

In ICCS 2016, 24 countries participated and five of those were Latin American: Chile, Mexico, Colombia, Peru, and Dominican Republic. These five countries showed the lowest performance among the 24 participants. Based on a knowledge scale defined by IEA, which had an average of 500 points and a standard deviation of 100 points, Colombia obtained an average score of 482 points, which was equal to the score achieved by Chile, and higher than the score received by Mexico (467 points), Peru (438 points), and Dominican Republic (381 points) (Icfes 2017). Compared to the level of performance achieved in 2009, Colombia showed a significant increase of 20 points, the largest increase among Latin-American countries and the seventh largest among all participating countries.

With regard to differences by gender, the results show that Colombian girls obtained a higher score than boys in the civic knowledge scale in 2016. Finally, the analysis of proficiency levels in Colombia revealed that the percentage of students at levels $A$ and $B$ (the highest levels in civic knowledge) increased by approximately 10 percentage points between 2009 and 2016 . This was the largest increase among the Latin American countries and the fourth largest among the participating countries.

In order to provide information on the students' performance in some of the more relevant areas and compare with other participating countries, Icfes published a National Report of Colombian Results (Icfes 2017). This presented ICCS results, comparing the performance between 2009 and 2016 as well as the differences with other participating countries. The document was targeted towards teachers, school managers, researchers, public policy decision makers, and others interested in civic and citizenship education. The results of the study present valuable information for the design and implementation of educational policies that pursue the improvement of civic education.

\section{Colombian Assessments Related to Civic and Citizenship Competences}

As mentioned before, Colombia participated in CIVED 1999, ICCS 2009, and ICCS 2016. These studies strengthened the understanding that support for our constitution requires quality standards for the development of young people's civic competences to prepare them to fully exercise their citizenship. It also made evident the importance of assessing how knowledge and skills were changing. To respond to this need, since 2002 Icfes has been assessing citizenship competences following what is established in the Standards, and in 2012 introduced the National Standardized Test of Citizenship Competences and the Citizen Actions and Attitudes Test (Icfes 2018). ICCS assesses knowledge and attitudes in civic and citizenship education; however, it does not evaluate competences like the handling of emotions or integrative competences, which are included in Colombia's national test.

The National Standardized Test of Citizenship Competences was administered in 2012 and most of the students were placed in the two lowest proficiency levels (61\% for grade 5 and $45 \%$ in grade 9). In addition, better results were found for girls compared to boys, for private schools as compared to public schools, and for urban schools as compared to rural schools (Icfes 2013). Moreover, the Citizen Actions and Attitudes Test (2012-2015) showed, for example, that the proportions of students accepting diversity were higher in grade 9 (between 75\% and 90\% between 2012 to 2015) than in grade 5 (between 65\% and 82\% for the same time interval) (Icfes 2016b). However, between 34\% and 65\% of grade 9 students agreed with statements that accepted breaking the law and between $38 \%$ and $57 \%$ agreed with statements that justified acts of corruption (Icfes 2016c). These results show that a substantial proportion of students express attitudes that are not favourable for peaceful coexistence and democracy. 
Such outcomes, along with ICCS results, should serve as a motivation for principals and local authorities to begin a process of deliberation about pedagogy to identify strengths and challenges in citizenship education, which could work toward improving students' skills (Icfes 2016a, 2016b, 2016c). As the Ministry of Education (2006b) recognized "it is important to contribute to the development of competences that can help children and young people to manage the complexity of life in society and to continue developing them-we must not forget that human beings are always developing these competences" (p. 154).

Additionally, besides Icfes assessments, other tests were conducted. In Bogotá, for seven years starting in 1997, the Basic Skills Assessment Project Tests (Proyecto de Evaluación de Competencias Básicas) were developed to assess students civic knowledge, as well as the degree of trust in political institutions or political actors (like the president, congressmen and congresswomen, the church, guerrilla groups). Moral and social development was also assessed (Torres and Díaz 2005; Jaramillo and Mesa 2009). Also, Los Andes University and the Secretariat of Education of Bogotá conducted the School Climate and Victimization Survey (Encuesta de Victimización y Clima Escolar) with grade 11 students and found large percentages of students reporting victimization by criminal acts like robbery (Chaux and Velásquez 2008).

Similarly, to ICCS results, these reports showed the need to address the issue of education for coexistence as an integral part of the educational process. It was clear that teachers lacked the necessary conceptual and methodological tools to work with these concepts (Restrepo 2006).

\section{Icfes National Workshops}

Since 2015, Icfes has offered workshops that provide guidelines and instruction to principals and teachers of public and private schools about the interpretation of results of the national standardized tests. The purpose is to improve the quality of education. The information given in these workshops is also offered in printed and digital media, for school staff who could not attend the session.

Between April and August of 2018, 126 workshops were held in 104 Colombian cities and approximately 10,000 principals and teachers attended, representing around 7000 schools. In that year, for the first time, the workshops included discussion about the results in ICCS 2016. The main purpose was to share with principals and teachers information about the test, the assessed competences, and the achievements and challenges that it implied for Colombia. It was important to point out how civic and citizenship education strengthens attitudes that favour democracy. Students with low levels of civic and citizenship knowledge are unaware of social and political problems in the country and tend to show favourable attitudes towards corruption and authoritarian governments as well as disobedience of the law (Icfes 2017).

To understand the utility of having included information about Colombia's ICCS 2016 results in the 2018 workshops, Icfes conducted a web survey (in November of 2018) with the participants, and more than 600 participants replied. This survey inquired about current strategies that schools have implemented regarding civic and citizenship education, and how these were improved by the information they received about ICCS 2016 in 2018. Most of the participants (89\%) were interested in getting involved in related projects, and $60 \%$ of the participants reported sharing the results with the other members of their schools. It is important to mention that the survey was designed to inquire about the way teachers who attended the workshops were using the information. This was only for internal purposes and was not published. For this reason results must be read and interpreted carefully.

The survey also inquired about possible changes in their curriculum or classes' content related to civic and citizenship education. About half of the educational community who replied reported they had made changes in their school curriculum or their practices on this matter. These changes were mainly related to the issue of peace, and some of them emphasize the implementation of the 
Peace Seminar and related seminars along with other factors. Furthermore, 19\% had conducted an additional inquiry into civic and citizenship education, mostly related to peaceful coexistence and community knowledge. Finally, 89\% said they would consider curricular improvements and activities with the community. More in-depth investigations should be pursued.

\section{Brief Discussion of Civic and Citizenship Education in Colombia}

\section{Colombia's Educational System Challenges}

As indicated previously, the Colombian Standards of Citizenship Competences offer a guide to civic and citizenship contents. These standards attempt to counteract recourse to violence by developing the civic and citizenship competences of students and teachers. The intention was to establish public and clear criteria, which would allow schools to establish basics levels of civic and citizenship education for children and young people. The standards are focused on three main components: peace and co-existence; democratic participation and responsibility; and, finally, valuing plurality and differences in identity. Cognitive, emotional, communicative, and integrative competences were identified (MEN 2011).

However, it is difficult to teach the relevant concepts in the way that the Standards of Citizenship Competences suggest. On the one hand, the standards state what competences are expected from students but do not explain how they might be developed by principals in the schools and teachers within the classrooms (Chaux 2009). Even with the efforts made by the Ministry of Education programs and private and local programs, it is not completely clear how schools can develop these competences. Additionally, the role given to schools by the local authorities usually emphasizes administrative and financial tasks, instead of focusing on their pedagogical and educative responsibilities (Pinilla and Torres 2016), which limits the clear development of civic and citizenship competences.

At the same time, given schools autonomy and the limitations of local authorities, the Ministry of National Education has limited control over the development of students' competences as the Standards of Citizenship Competences suggest. This lack of specificity and oversight by local authorities and government presents a challenge in translating the standards to practice and motivating local institutions to support their implementation (Berkowitz and Bustamante 2013). Based on these observations of civic and citizenship education in the country, Noonan (2010) cautioned that the standards' implementation is often neglected.

Icfes' preliminary survey results following the 2018 workshops showed that civic and citizenship education was mostly understood by teachers as related to life plans, peace, coexistence, ethics, and society. Many respondents did not mention key concepts such as democracy, citizen participation, responsibility for individual actions, and responsibility for the environment. Similarly, González-Valencia and Santisteban-Fernandez (2016) conducted qualitative research using instruments like structured surveys, interviews, focus groups, and the observation of classes. One of their conclusions was that Colombian teachers' knowledge about civic and citizenship is characterized by very concrete beliefs that lack depth of understanding. For example, the authors highlight that some teachers argued that: "a citizen is that person who has the legal age and an identification document," and that "politics and government are synonymous." Also, some answers from the Icfes workshop survey showed that civic and citizenship education could have a role in the resolution of conflicts and respect for racial and cultural diversity.

Additionally, the principle of school autonomy has justified a wide range of curricular content or pedagogical practices as part of the subjects related to civic and citizenship education. For example, school curriculums are mostly focused on the areas that are assessed the most frequently-language and mathematics (Berkowitz and Bustamente 2013)-and leave aside civic and citizenship concepts and practices. Some argue that these concepts could be taught as 
underlying all areas of teachers' training (Jaramillo and Cepeda 2004; Patti and Espinosa 2007; Chaux 2009; González-Valencia and Santisteban-Fernández 2016). Further, design strategies to integrate civic and citizenship education into pedagogical practices should be developed. In this respect, Browes (2017) said that more concrete guidelines and greater support and training for schools' leaders and teachers are needed, as well as tools and materials to enhance currently available contents and pedagogy. This is especially important when schools have a high administrative and financial burden, which limits principals' time to focus on pedagogical and educative strategies about civic and citizenship education.

Another possible explanation for schools and teachers' gaps in civic and citizenship knowledge might be related to traditional teacher training, which tends to mask the social problems that the country experiences, and has traditionally been focused on social sciences like history and geography (González-Valencia and Santisteban-Fernández 2016). In this context, Browes (2017) believes that traditional approaches, which include emphasis on religion, patriotism, and the family, have neglected important topics like justice, peace, democracy, and participation. Nowadays, there is a tendency to implement traditional civic education that responds to the idea of teaching the Constitution, but it is characterized by a lack of instruction in critical thinking or application to practice (González-Valencia and Santisteban-Fernández 2016). Importantly, teaching civic and citizenship competences may be perceived as dangerous by teachers in areas where guerrillas or other illegal armed groups are present (Patti and Espinosa 2007).

\section{Social and Contextual Challenges}

There are several ways of framing these problems. On one hand, Noonan (2010) states that Colombia's armed conflict stands as a threat to the stability of democracy, as well as an obstacle for the development of peaceful, civically engaged citizens and community-mindedness. On the other, Pinilla and Torres (2006) argue that too little attention is paid to social inequalities and political exclusion as reasons for the social behaviour of Colombians. Similarly, Rodríguez et al. (2007), and Berkowitz and Bustamante (2013), attribute these difficulties to a deficiency in the social policies of the State during the 1990s; this situation may have contributed to negative perceptions from young people regarding government institutions. In sum, the challenges the country has faced and currently encounters, regarding the political, economic, and social realms, could be seen as both causes and consequences of deficiencies in the teaching of civic and citizenship.

In this context, teaching civic and citizenship concepts has been difficult in Colombia because violence seems to be so embedded in the country's history, so that many people seem to think that this is an appropriate way to solve problems (Jaramillo and Mesa 2009). This represents a threat to civil society. Inadequate civic and citizenship education may increase the likelihood that students internalize attitudes accepting undemocratic practices, disregarding how democratic institutions should work or how they have worked in Colombia and other countries. Besides, given the existence of poverty, inequality, and unemployment (as in most Latin American countries), those attitudes might continue to be understandable responses to such issues. In fact, Jaramillo and Mesa (2009) recognize that the poverty in which many young people live predispose them to distorted concepts of democracy.

It has been recently suggested that Colombia's education system needs to recognize that a space should be created for reflection and ways to increase motivation. This could happen through the analysis of the students' daily relationships inside and outside school settings (Rodríguez et al. 2017). Being a good citizen does not rely exclusively on knowledge of concepts; instead, it is widely associated with the skills that allow one to relate positively to others. This can be developed through practical activities and discussing reflections about students' actions in specific contexts including the school (Jaramillo and Cepeda 2004). 


\section{Summary and Concluding Thoughts}

This chapter describes the context of civic and citizenship education in Colombia, as well as Colombia's participation in ICCS, its influence on the National Standardized Test of Citizenship Competences and the Citizen Actions and Attitudes Test, and how members of the school community who attended the Icfes 2018 workshops used the results from ICCS 2016. Finally, there is a discussion about barriers to teaching civic and citizenship education. Colombia has made several efforts to improve the civic and citizenship knowledge of students. For instance, the country has participated in international studies like ICCS and the earlier CIVED. The National Government has developed the Colombian Standards of Citizenship Competences and has implemented the national test of civic and citizenship education. Also, civic and citizenship education has changed in response to the new context of the country after the peace agreement, and the educational system as a whole has been involved in this process of adjustment. As part of this, Icfes has been making an additional effort through the assessment of civic and citizenship education, the preparation of workshops with the schools, and the dissemination of a diverse set of documents and reports. The purpose of these strategies is for teachers and principals to understand the results and use the information to design improvement plans that allow students to experience a more intensive development of these competences.

Furthermore, the existence of gaps in civic and citizenship education represents both a challenge and an opportunity to transform education systems and target civic issues in Latin America. These include corruption and civil disobedience. In this respect, the Colombian experience suggests how researchers and experts in civic and citizenship areas can join policymakers and other political groups to broadly influence the nature and effectiveness of educational efforts not only to promote academic achievement but also to promote the positive development of socioemotional and citizenship competences in the Colombian population (Berkowitz and Bustamante 2013).

At a local level, the lack of cohesion between government policies and local needs, practices, and expectations (Pinilla and Torres 2006), is one of the reasons why schools have minimal time and resources to focus on pedagogical and educational activities. Additionally, teachers' initial formation used to be focused on factual contents relevant for history and geography with less emphasis on didactic training oriented to teaching civic knowledge and developing social thinking (González-Valencia and Santisteban-Fernandez 2016). As a result, the existence of schools' and teachers' pedagogical weaknesses makes it necessary for civic and citizenship studies in the future to inquire about teachers' training and knowledge in this area, as well as perceptions of the implementation of the curriculum in the schools.

A first step could be the assessment of the knowledge, pedagogical practices, and perceptions of teachers who teach civic and citizenship subjects. It would be important to measure teachers' academic training in this matter and how schools are selecting them to work in civic and citizenship education. Also, it would be relevant to understand the guidance that schools are offering all teachers to teach this topic in a transversal way. This could shed light on why countries in Latin America consistently show low performance in the assessed areas in ICCS. With this information, Colombia and other countries could take actions to effectively implement different strategies and improve their practices in civics and citizenship education in the classroom.

\section{References}

Berkowitz, M., \& Bustamante, A. (2013). Using research to set priorities for character education in schools: A global perspective. KEDI Journal of Educational Policy, KJEP Special Issue, 7-20.

Bickmore, K., Kaderi, A., \& Guerra-Sua, Á. (2017). Creating capacities for peacebuilding citizenship: history and social studies curricula in Bangladesh, Canada, Colombia, and México. Journal of Peace Education,14(3), 282-309. 
Browes, N. (2017). Global citizenship concepts in the curricula of four countries. Current and critical issues in curriculum, learning and assessment. November 2017, No. 16 IBE/2017/WP/CD/16. Geneva, Switzerland: UNESCO International Bureau of Education and Asia-Pacific Centre of Education for International Understanding.

Chaux, E. (2009). Citizenship competencies in the midst of a violent political conflict: The Colombian educational response. Harvard Educational Review, 79(1), 84-93.

Chaux, E., \& Velasquez, A. (2008). Violencia en los colegios de Bogota: Contraste internacional y algunas recomendaciones. Revista Colombiana de Educación, 55, 13-37.

Chaux, E., Lleras, J., \& Velásquez, A. (2012). Competencias ciudadanas: de los estándares al aula: una propuesta de integración a las áreas académicas. Bogotá, Colombia: Universidad de Los Andes.

Congreso de la República de Colombia. (1994a). Ley 115 de 1994: Ley General de Educación. Bogotá, Colombia: Author.

Congreso de la República de Colombia. (1994b). Decreto 1860 de 1994 - Por el cual se reglamenta parcialmente la Ley 115 de 1994, en los aspectos pedagógicos y organizativos generales. Bogotá, Colombia: Author.

Congreso de la República de Colombia. (2014). Ley 1732 de 2014: Por la cual se establece la cátedra de la paz en todas las IE del País. Bogotá, Colombia: Author.

Congreso de la República de Colombia. (2015). Decreto 1038 de 2015: Por el cual se reglamenta la Cátedra de la Paz. Bogotá, Colombia: Author.

Gonzáles, A. (2013). El profesorado en formación y las finalidades de la enseñanza de las ciencias sociales. Uni-pluriversidad, 13(2), 24-34.

González-Valencia, G. A., \& Santisteban-Fernández, A. (2016). La formación ciudadana en la educación obligatoria en Colombia: entre la tradición y la transformación. Educación y Educadores, 19(1), 89-102. https://doi.org/10.5294/edu.2016.19.1.5

Herrera, M. (2008a). Esbozos históricos sobre cultura política y formación ciudadana en Colombia: actores, sujetos y escenarios. Ponencia presentada en el seminario formación y ciudadanía política en Colombia: un reto que no da espera. https://docplayer.es/14000219-Esbozos-historicos-sobre-cultura-politica-yformacion-ciudadana-en-colombia-actores-sujetos-y-escenarios-1.html

Herrera, M. (2008b). Políticas públicas en educación ciudadana en Colombia y América Latina: La arena de lucha del campo intelectual en la historia reciente. Historia de la Educación - Anuario, 2008, 9.

Herrera, M., Díaz, A. P. \& Suaza, L. (2003). La identidad nacional en los textos escolares de ciencias sociales: Colombia: 1900-1950. U. Pedagógica Nacional.

Icfes. (2013). Resultados nacionales censales en Competencias Ciudadanas. SABER 3, 5 y 9, 2012. Bogotá, Colombia: Instituto Colombiano para la Evaluación de la Educación, Icfes.

Icfes. (2016a). Competencias Ciudadanas: roles de intimidación escolar y tipos de agresión. Boletín Saber en Breve No 2. Bogotá, Colombia: Instituto Colombiano para la Evaluación de la Educación, Icfes. Icfes. (2016b). Competencias Ciudadanas: Participación y responsabilidad democrática. Boletín Saber en Breve No 7. Bogotá, Colombia: Instituto Colombiano para la Evaluación de la Educación, Icfes.

Icfes. (2016c). Competencias Ciudadanas: pluralidad, identidad y valoración de las diferencias. Boletín Saber en Breve No 10. Bogotá, Colombia: Instituto Colombiano para la Evaluación de la Educación, Icfes. Icfes. (2017). Estudio Internacional de Educación Cívica y Ciudadana ICCS 2016. Informe nacional para Colombia 2017. Bogotá, Colombia: Instituto Colombiano para la Evaluación de la Educación, Icfes.

Icfes. (2018). Marco de referencia para la evaluación. Prueba de competencias ciudadanas, Saber $5^{\circ}$, Saber $9^{\circ}$, Saber $11^{\circ}$, Saber TyT y Saber Pro. Bogotá, Colombia: Instituto Colombiano para la Evaluación de la Educación, Icfes.

Jaramillo, R., \& Cepeda, A. (2004). Acuerdos mínimos para desarrollar habilidades para la paz. Revista internacional Magisterio. Educación y Pedagogía, 9, 32-33.

Jaramillo, R., \& Mesa, J. A. (2009). Citizenship education as a response to Colombia's social and political context. Journal of Moral Education, 38(4), 467-487.

Largo, A. B. G., Laguado, J. E. C., \& Omaña, G. A. R. (2014). La realidad de la descentralización en Colombia a partir de la Constitucion de 1991. Hipotesis Libre, (9).

Ministerio de Educación Nacional de Colombia. (2002). Resolución 1278 de 2002 (19 de julio). Bogotá, Colombia: Author. 
Ministerio de Educación Nacional de Colombia. (2004a). Resolución 1730 de 2004 (18 de junio). Bogotá, Colombia: Author.

Ministerio de Educación Nacional de Colombia. (2004b). Estándares Básicos de Competencias Ciudadanas. Bogotá, Colombia: Author.

Ministerio de Educación Nacional de Colombia. (2005). Comprensiones Sobre Ciudadanía Veintitres Expertos Internacionales de cómo Construir Ciudadanía y Aprender a Entenderse. Bogotá, Colombia: Cooperativa Editorial Magisterio.

Ministerio de Educación Nacional de Colombia (2006a). Portafolio De Programas e Iniciativas En Competencias Ciudadanas. Bogotá, Colombia: Author.

Ministerio de Educación Nacional de Colombia (2006b). Estándares básicos en competencias ciudadanas: formar para la ciudadanía sí es posible. Bogotá, Colombia: Author.

Ministerio de Educación Nacional de Colombia. (2011). Orientaciones para la institucionalización de las competencias ciudadanas, Cartilla 1: Brújula de competencias ciudadanas. Bogotá, Colombia: Author.

Noonan, J. M. (2010). Re-imagining teacher professional development and citizenship education: Lessons for import from Colombia. Paper prepared for the Annual Meeting of the Comparative and International Education Society (54th, Mar 3, 2010). http://files.eric.ed.gov/fulltext/ED508978.pdf

Patti, J. \& Espinosa, A. (2007). Citizenship competencies in Colombia: Learning from policy and practice. Conflict Resolution Quarterly, 25(1), 109-125.

Peláez, A., \& Márquez, D. (2006). Educación para la democracia y la formación política en Colombia: 1980-2006. Un estado del arte. Fundación Konrad Adenauer.

Pinilla, A., \& Torres, J. (2006). De la educación para la democracia a la formación ciudadana: una década de incertidumbres. Bogotá, Colombia: Universidad Pedagógica Nacional/Instituto para el Desarrollo Pedagógico y la Investigación Educativa-IPEP.

Ramírez-Orozco, M. (2014). Aproximación bibliográfica a la construcción de la paz en Colombia. Revista de la Universidad de la Salle, (63), 23-43.

Ramos, C., Nieto, A., \& Chaux, E. (2007). Aulas en paz. Revista interamericana de educación para la democracia, 1(1), 36-56.

Restrepo, J. (2006). Estándares básicos en competencias ciudadanas: una aproximación al problema de la formación ciudadana en Colombia. Papel Político, 11(1), 137-176.

Rodríguez, A., León, S., \& Guerra, Y. (2007). Competencias ciudadanas aplicadas a la educación en Colombia. Educación y Desarrollo Social, 1(2), 140-157.

Schulz, W., Ainley, J., Fraillon, J., Losito, B., \& Agrusti, G. (2016). IEA International Civic and Citizenship Education Study 2016 assessment framework. Cham, Switzerland: Springer. https://link.springer.com/ content/pdf/10.1007\%2F978-3-319-39357-5.pdf

Torres, J., \& Díaz, A. (2005). Las vías de la educación ciudadana en Colombia. Revista Folios, (21), 47-64.

Velásquez, A., Chaux, E., \& Ministerio de Educación Nacional (2017). Orientaciones Generales para la Implementación de la Cátedra de la Paz en los establecimientos educativos de prescolar. Bogota, Colombia: Ministerio de Educación Nacional de Colombia.

Open Access This chapter is licensed under the terms of the Creative Commons Attribution-NonCommercial 4.0 International License (http://creativecommons.org/licenses/by-nc/4.0/), which permits any noncommercial use, sharing, adaptation, distribution and reproduction in any medium or format, as long as you give appropriate credit to the original author(s) and the source, provide a link to the Creative Commons license and indicate if changes were made.

The images or other third party material in this chapter are included in the chapter's Creative Commons license, unless indicated otherwise in a credit line to the material. If material is not included in the chapter's Creative Commons license and your intended use is not permitted by statutory regulation or exceeds the permitted use, you will need to obtain permission directly from the copyright holder. 